\title{
Potentially toxic elements in the riparian soils of the Sava River
}

\author{
Milica Marković ${ }^{1} \cdot$ Tea Zuliani $^{2} \cdot$ Snežana Belanović Simić ${ }^{3}$ - Zorana Mataruga ${ }^{1} \cdot$ Olga Kostić $^{1} \cdot$ Snežana Jarić $^{1}$. \\ Janja Vidmar ${ }^{2} \cdot$ Radmila Milačič $^{2}$ • Janez Ščančar ${ }^{2}$ - Miroslava Mitrović ${ }^{1} \cdot$ Pavle Pavlović $^{1}$
}

Received: 1 December 2017 / Accepted: 22 June 2018 / Published online: 4 July 2018

(C) The Author(s) 2018

\begin{abstract}
Purpose Riparian zone contamination is a growing problem for several European catchments due to high anthropogenic pressures. This study investigates $\mathrm{As}, \mathrm{Cd}, \mathrm{Cr}, \mathrm{Cu}, \mathrm{Ni}, \mathrm{Pb}$, and $\mathrm{Zn}$ concentrations in the Sava River riparian zone, characterized by wide agricultural areas, various geological substrates, and different types of industrial pollution. The accumulation and mobility of these elements were studied because they are listed as priority substances in the Water Framework Directive and environmental objectives for surface waters.

Materials and methods Sampling was performed during the sampling campaign of the EU 7th FW-funded GLOBAQUA project in September 2015 during a low-water event. Soil samples were collected along the Sava River at 12 selected sampling sites, from a depth of $0-30 \mathrm{~cm}$, at a distance of 10-15 $\mathrm{m}$ from the river bank. The extent of pollution was estimated by determining total and readily soluble element concentrations in the soils. Potential ecological risk and the source of the selected elements in the soils was determined using the enrichment factor (EF), potential ecological risk index (RI), and statistical methods such as the principal component analysis (PCA) and multiple linear regression analysis (MLRA).

Results and discussion This study showed that concentrations of the selected elements increase along the Sava. In terms of origin, PCA and MLRA indicated that $\mathrm{Cr}$ and $\mathrm{Ni}$ in soils are predominantly lithogenic, while $\mathrm{As}, \mathrm{Cd}, \mathrm{Pb}$, and $\mathrm{Zn}$ are both lithogenic and anthropogenic (ore deposits, industry, and agriculture). PCA singled out $\mathrm{Cu}$ since its origin in soil is most probably from specific point-source pollution. EF was generally minor to moderate for most of the examined elements, apart from $\mathrm{Cu}$, for which the $\mathrm{EF}$ was significant at one sampling site. Overall ecological risk (RI) fell within the low-risk category for most sites, apart from Belgrade sampling site (BEO), where high total $\mathrm{Cd}$ content affected individual and overall ecological risk indicators, indicating $\mathrm{Cd}$ could represent a considerable ecological risk for the downstream riparian zone.

Conclusions At downstream sites, there was a noticeable increase in PTE content, with $\mathrm{Cd}, \mathrm{Cr}, \mathrm{Ni}$, and $\mathrm{Zn}$ exceeding the proposed threshold values for European soils, indicating rising contamination in riparian soils. In terms of the ecological risk, only $\mathrm{Cd}$ could pose a potential ecological threat for the downstream riparian zone.
\end{abstract}

Keywords Ecological risk index $\cdot$ Enrichment factor $\cdot$ Potentially toxic elements $\cdot$ Riparian soil $\cdot$ The Sava River

Responsible editor: Vito Ferro

Electronic supplementary material The online version of this article (https://doi.org/10.1007/s11368-018-2071-7) contains supplementary material, which is available to authorized users.

Pavle Pavlović

ppavle@ibiss.bg.ac.rs

1 Department of Ecology, Institute for Biological Research 'Siniša Stanković', University of Belgrade, Bulevar despota Stefana 142, 11060 Belgrade, Serbia

2 Department of Environmental Sciences, Jožef Stefan Institute, Jamova 39, 1000 Ljubljana, Slovenia

3 Faculty of Forestry, University of Belgrade, Kneza Višeslava 1, Belgrade 11000, Serbia

\section{Introduction}

Riparian zones are unique, dynamic systems whose size is dependent on the topography. Often characterized by high biodiversity thanks to the heterogeneous environment created by frequent flooding, fluctuations in the groundwater system, and deposition of sediments (Naiman and Décamps 1997), their boundaries can vary greatly. Generally, riparian zones extend outwards from the river channel to the limits of flooding and travel into the canopy of riverside vegetation. They play a key role in the functioning of aquatic ecosystems, affecting chemical, physical, and biological processes (Sedell et al. 1991; Naiman and Décamps 1997; Pusey and Arthington 2003). Riverine riparian areas influence chemical 
loads from diffuse industrial and agricultural sources (runoff) and reduce in-stream pollution during flooding (Karr and Gorman 1975), while riparian soil acts as an important sink for pollutants, especially heavy metals from river water or upland, through adsorption and sedimentation (Zhang et al. 2010; Izquierdo et al. 2013). These soils are under intense pressure from various anthropogenic sources of pollutants, which could contribute significantly to multiple stress conditions (Navarro-Ortega et al. 2015; Wang et al. 2015). In fact, as a complex and dynamic component of aquatic ecosystems, riparian soils are a suitable medium for monitoring heavy metal pollution.

Past research has paid relatively little attention to wetland soils, especially floodplain soils, despite them frequently having high levels of pollutants (Rinklebe et al. 2007), and with the progressive development of riverbanks in urban areas, on farmland, and in industrial zones, contamination problems will only increase markedly in the years to come (SaintLaurent et al. 2013). Among various pollutants, chemical elements may contribute significantly to the overall pollution of riverine environments. Most often, their origin is lithogenic, although anthropogenic activities may increase concentrations and lead to contamination (Bain et al. 2012; Jiang et al. 2017). Unlike the former, elements of anthropogenic origin are highly mobile and bioavailable, and thus more likely to impact negatively on aquatic ecosystems (Tessier and Campbell 1987). To assess the origin of heavy metals in soils, multivariate statistical analyses, like principal component analysis (PCA), are often performed (Borůvka et al. 2005; Cakmak et al. 2015; Jiang et al. 2017), while the enrichment factor (EF) and ecological risk index (RI) are frequently used to assess the ecological risk potentially toxic elements (PTE) can pose to riverine environments (Hakanson 1980; Hu et al. 2013; Sakan et al. 2015; Čakmak et al. 2018).

Flowing through four countries (Slovenia, Croatia, Bosnia and Herzegovina, and Serbia), the Sava River is the major drainage basin $\left(97,713.20 \mathrm{~km}^{2}\right)$ of Southeastern Europe and the largest tributary to the River Danube (ISRBC 2013). The Sava River Basin (SRB) is characterized by high biological diversity and industrial and economic potential. The Sava is also one of the main sources of drinking water for its riparian population. Sources of PTE in the Sava's riparian zones are diverse, relating mostly to chemical weathering of parent material and various anthropogenic factors (Vertačnik et al. 1995; Orescanin et al. 2004; Crnković et al. 2008; Markovics et al. 2010; Vuković et al. 2011; Šajn and Gosar 2014; Ščančar et al. 2015). These factors include industrial and intensive agricultural activities, urbanization, and, in the Sava's lower reaches, non-treated municipal sewage (Komatina and Grošelj 2015). Contaminants from diffuse and point sources have a major impact on water quality and sediments (Ščančar et al. 2015), while hydrological conditions significantly impact pollution levels. Namely, during flooding, water covers the riparian soil and if this is contaminated with PTE, these may be released into the overlying water and accumulate in sediments (Milačič et al. 2017). Due to the persistence of many pollutants and their bioaccumulation potential, sediments represent a serious threat to riverine ecosystems (Vuković et al. 2011). Studies on heavy metals and other pollutants in river water and sediments have multiplied in recent years, especially for large rivers such as the Danube (Woitke et al. 2003; Crnković et al. 2008; Pavlović et al. 2016), the Sava and their tributaries the Drava and the Kolubara (Orescanin et al. 2004; Crnković et al. 2008; Vuković et al. 2011; Vidmar et al. 2017; Milačič et al. 2017; Čakmak et al. 2018), the Tisza (Sakan and Đorđević 2010), and the Po (Vignati et al. 2003). Other researchers have studied contamination of riparian soil along the Danube (Pavlović et al. 2016), the Sava and their tributaries the Drava and the Kolubara (Vertačnik et al. 1995; Halamić et al. 2003; Šajn et al. 2011; Šajn and Gosar 2014; Čakmak et al. 2018), and the Odra (Ciesielczuk et al. 2014), but such studies are documented much scarcely.

The aim of the present study was to investigate the extent of soil contamination by PTE ( $\mathrm{As}, \mathrm{Cd}, \mathrm{Cr}, \mathrm{Cu}, \mathrm{Ni}, \mathrm{Pb}$, and $\mathrm{Zn}$ ) in the Sava's riparian zone, to identify sources of these elements in riparian soil, and to assess the ecological risk PTE may pose to such soil. Trace elements were selected in line with the list of priority substances in the field of water policy within the Water Framework Directive (WFD) and its daughter directives: Directive 2000/60/EC (EC 2000) and Directive 2013/ 39/EU (EU 2013).

\section{Material and methods}

\subsection{Study area and sampling}

The study area covered the Sava's entire $945 \mathrm{~km}$, from its source (Sava Dolinka) to its confluence with the Danube, with sampling sites selected in Slovenia, Croatia, and Serbia. Characterized by a diverse landscape, the SRB can be roughly divided into three parts - upper, middle, and lowland. The 265-km upper reach, including Sava Dolinka, is dominated by mountainous terrain, the shortest middle part $(129 \mathrm{~km})$ flows through lowland, and the 597-km lower section flows through plains and is characterized by a very low declination and a wide water channel (ISRBC 2013). Specific hydrological and soil characteristics have resulted in vegetation diversity, including 167 protected areas, and while riparian soils are rich in organic residues, the humus content is normally low because these residues are covered by river sediment during high-water events, preventing decomposition (Karadžić et al. 2015).

Sampling was conducted along the river during a low-water event from 1 to 9 September 2015 as part of the GLOBAQUA project (Navarro-Ortega et al. 2015). Twelve sampling 
localities were selected based on their representativeness in terms of different pollution sources/anthropogenic pressures (Fig. 1). The sampling sites' main characteristics are presented in Table S1 (Electronic Supplementary Material). Soil samples were taken at each site from a depth of $0-30 \mathrm{~cm}$ so as to cover both lithogenic and anthropogenic element sources and at a distance of $10-15 \mathrm{~m}$ from the river bank because this area usually floods during high-water events and is thus prone to the effects of pollutants from water and sediments. Five subsamples per sampling site were combined into one composite sample, which was transferred to PVC buckets and thoroughly homogenized before further treatment. Samples were kept in the dark at $4{ }^{\circ} \mathrm{C}$ before being analyzed for trace element content. All analyses were performed in five replicates and the results expressed on a dry mass basis.

\subsection{Instrumentation and reagents}

Microwave digestion of soil samples was performed on a CEM Corporation (Matthews, NC, USA) MARS 5 Microwave System. Element concentrations in digested samples and soil fractions extracted in $0.11 \mathrm{~mol} \mathrm{~L}^{-1}$ acetic acid were determined using inductively coupled plasma mass spectrometry (ICP-MS) (7700×, Agilent Technologies, Tokyo, Japan). For sample preparation, suprapure acids (Merck, Darmstadt, Germany) and Milli-Q water (Direct-Q 5 Ultrapure water system, $18 \mathrm{M} \Omega \mathrm{cm}$, Millipore Watertown, MA, USA) were used, while other chemicals used were of analytical reagent grade or higher purity. ICP multi-element standard solution IV CertiPUR containing $1000 \mathrm{mg} \mathrm{L}^{-1} \pm$ $10 \mathrm{mg} \mathrm{L}^{-1}$ in $1 \mathrm{~mol} \mathrm{~L}^{-1} \mathrm{HNO}_{3}$ of different elements was obtained from Merck. Samples were filtered using 0.45- $\mu \mathrm{m}$ Minisart cellulose nitrate membrane filters (Sartorius, Goettingen, Germany).

\subsection{Quality control}

Certified reference materials SPS-SW1 Quality Control Material for Surface Water Analysis from SPS Spectrapure Standards AS (Oslo, Norway) and CRM 320R Trace Elements in River Sediment from the Community Bureau of Reference (Geel, Belgium) were used to check accuracy. The data presented in Table S2 (Electronic Supplementary Material) correlated closely with the reported certified values (better than $\pm 5 \%$ ), thus confirming the accuracy of the analytical procedures applied.

\subsection{Determination of total element concentrations in soil}

To determine total element concentrations, approximately $0.25 \mathrm{~g}$ of soil was transferred to Teflon vessels and $4 \mathrm{~mL}$ $\mathrm{HNO}_{3}$ (s.p.), $2 \mathrm{~mL} \mathrm{HF}$ (s.p.), and $1 \mathrm{~mL} \mathrm{HCl}$ (s.p.) were added.
The vessels were covered and subjected to microwaveassisted digestion by ramping the temperature to $200{ }^{\circ} \mathrm{C}$ in $30 \mathrm{~min}$, maintaining the temperature for $60 \mathrm{~min}$ and then cooling the contents over the next $30 \mathrm{~min} .12 .5 \mathrm{~mL} \mathrm{H}_{3} \mathrm{BO}_{3}$ (s.p.) (4\% aqueous solution) was then added for complexation of fluorides and the contents were digested again by ramping the temperature to $200{ }^{\circ} \mathrm{C}$ in $15 \mathrm{~min}$, maintaining the temperature for $30 \mathrm{~min}$ and then cooling the contents over the next 30 min (Ščančar et al. 2007). After digestion, clear solutions were obtained. The contents were transferred quantitatively to $30-\mathrm{mL}$ graduated polypropylene tubes and filled to the mark with water. The same procedure, but minus the soil samples, was applied to determine blanks. Element concentrations in digested soil samples were determined by ICP-MS.

\subsection{Determination of readily soluble element concentrations in $0.11 \mathrm{~mol} \mathrm{~L}^{-1}$ acetic acid}

To determine readily soluble, potentially bioavailable element concentrations, acetic acid extraction was applied (Quevauviller et al. 1997; Milačič et al. 2010). Approximately $2 \mathrm{~g}$ of moist soil sample was weighed into a $40-\mathrm{mL}$ centrifuge tube with $20 \mathrm{~mL}$ $0.11 \mathrm{~mol} \mathrm{~L}^{-1}$ acetic acid added. Samples were shaken on a mechanical shaker (300 rpm) for $16 \mathrm{~h}$, centrifuged (9000 rpm, $20 \mathrm{~min}$ ), and filtered through a $0.45-\mu \mathrm{m}$ membrane filter. Element concentrations were determined by ICP-MS.

\subsection{Calculation of the enrichment factor and ecological risk index}

A geochemical approach, such as the enrichment factor (EF) and ecological risk index (RI), has been widely used to assess the environmental burden of elements accumulated in soils and sediments (Hu et al. 2013; Sakan et al. 2015; Čakmak et al. 2018). The EF was calculated according to the following equation:

$\mathrm{EF}=\frac{\left(C_{x} / C_{\mathrm{Mn}}\right) \text { soil }}{\left(C_{x} / C_{\mathrm{Mn}}\right) \text { background }}$

where $\left(C_{x} / C_{M n}\right)$ soil is the ratio between concentrations of the potentially enriched element $C_{x}$ and Mn concentrations $\left(C_{\mathrm{Mn}}\right)$ in soil samples, and $\left(C_{x} / C_{\mathrm{Mn}}\right)$ background is the ratio of the referenced background values. Manganese was used as the reference background element due to a lack of Al data, with its feasibility confirmed by Loska et al. (1997), as Mn is mainly of lithogenic origin and its anthropogenic sources are minimal. Principal component analysis (PCA) can assist when selecting the reference background element (Birch 2017), as can a high correlation with the elements studied (N'guessan et al. 2009). In our study, using Mn as the reference metal was justified through PCA, which identified it as being of lithogenic origin and in significant correlation with most of 


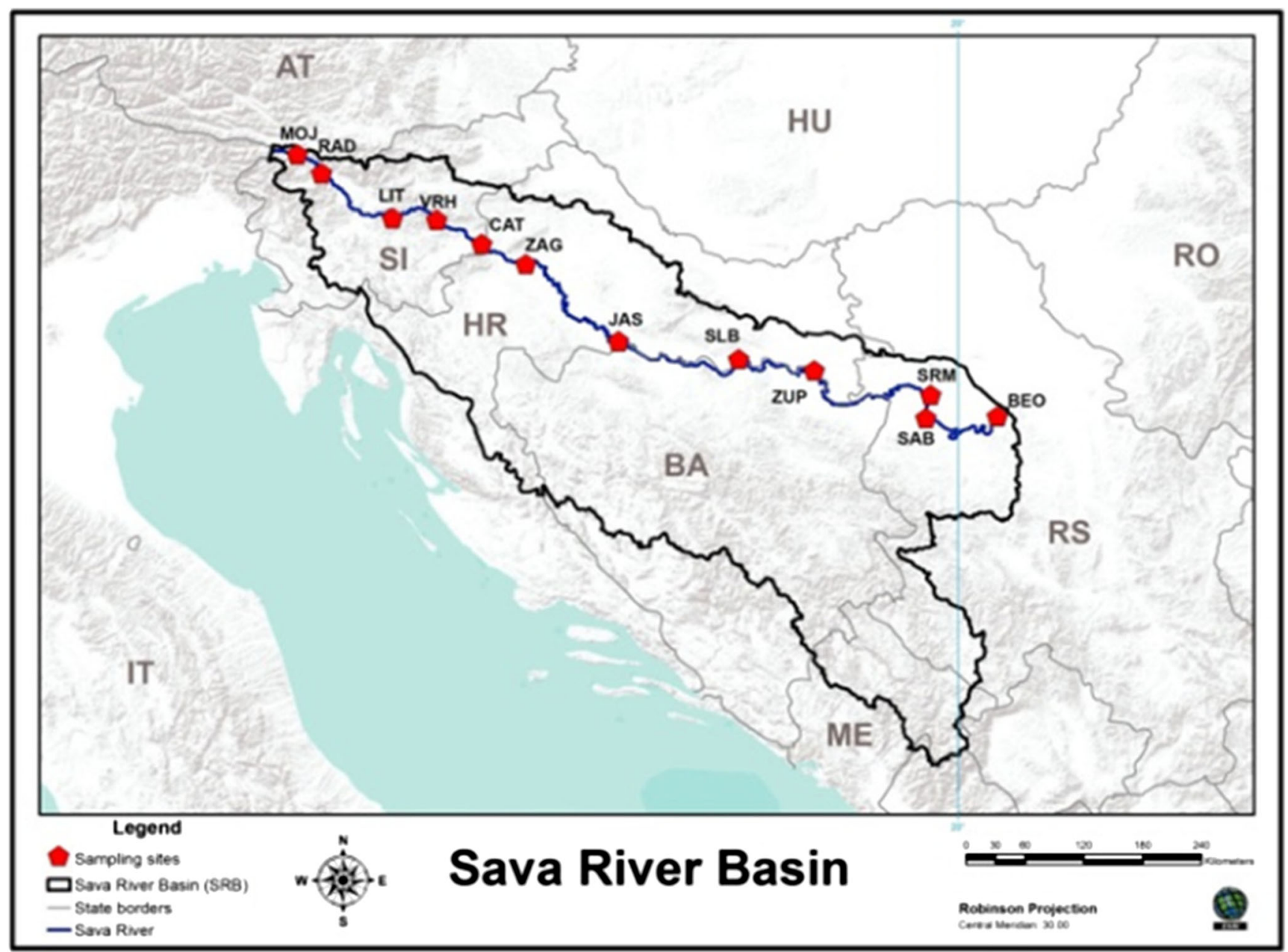

Fig. 1 Sava River sampling sites (sampling in September 2015): 1, Mojstrana (SI) MOJ; 2, Radovljica (SI) RAD; 3, Litija (SI) LIT; 4, Vrhovo (SI) VRH; 5, Čatež (SI) CAT; 6, Zagreb (HR) ZAG; 7,

the studied elements, in particular with $\mathrm{Cr}$ and $\mathrm{Ni}$. Five contamination categories are recognized on the basis of the enrichment factor (Sutherland 2000): EF $<2$ represents deficiency to minimal enrichment; EF 2-5, moderate enrichment; EF 5-20, significant enrichment; EF 20-40, very high enrichment; and EF > 40, extremely high enrichment.

The potential ecological risk index (RI) takes into account the concentration effects of various trace metals in soils, the toxic effects of different metals, and the synergistic effects of multiple element complex pollution as defined by Hakanson (1980). The RI was calculated as the sum of pollutant risk factors, using the equation:

$\mathrm{RI}=\sum E_{i}$

where $E_{i}$ represents a single risk factor for trace element $i$ and is defined as:

$E_{i}=T_{i} f_{i}=T_{i} \frac{C_{i}}{B_{i}}$
Jasenovac (HR) JAS; 8, Slavonski Brod (HR) SLB; 9, Županja (HR) ZUP; 10, Sremska Mitrovica (RS) SRM; 11, Šabac (RS) SAB; 12, Belgrade (RS) BEO

where $T_{\mathrm{i}}$ is the toxic response for trace element $i$. The $T_{\mathrm{i}}$ values for $\mathrm{Cd}, \mathrm{As}, \mathrm{Ni}, \mathrm{Cu}, \mathrm{Pb}, \mathrm{Cr}$, and $\mathrm{Zn}$ are 30, 10, 5, 5, 5, 2, and 1 respectively. $f_{\mathrm{i}}$ is the ratio of the measured concentration $C_{\mathrm{i}}$ to the calculated background concentration $B_{\mathrm{i}}$ in soils. The potential ecological risk of trace elements in soils was classified into five categories based on $E_{\mathrm{i}}$ and four categories based on RI (Hakanson 1980): $E_{i}<40$ represents low potential ecological risk; $40 \leq E_{i}<80$, moderate potential ecological risk; $80 \leq$ $E_{i}<160$, considerable potential ecological risk; $160 \leq E_{i}<$ 320 , high potential ecological risk; and $E_{i} \geq 320$, very high potential ecological risk; while $\mathrm{RI}<150$ represents low risk; $150 \leq \mathrm{RI}<300$, moderate risk; $300 \leq \mathrm{RI}<600$, considerable risk; and $\mathrm{RI} \geq 600$, very high risk.

\subsection{Statistical analyses}

To assess the origin (natural vs. anthropogenic) of the studied elements, multivariate analyses, such as the Pearson correlation, PCA, and multiple linear regression analysis (MLRA), were used. Descriptive and multivariate statistical analyses 
were performed using MS Excel 2010 and SPSS version 20 software (SPSS, v21 2009). The arithmetical median method was used to calculate toxic element background values for soils in Serbia (Mrvić et al. 2011), Slovenia (Slovenian Environment Agency 2017), and Croatia (Halamić et al. 2012).

\section{Results}

\subsection{Analysis of trace element concentrations in riparian soils}

Total and readily soluble $\mathrm{As}, \mathrm{Cd}, \mathrm{Cr}, \mathrm{Cu}, \mathrm{Ni}, \mathrm{Pb}$, and $\mathrm{Zn}$ concentrations in soils were determined to evaluate the extent of pollution in the Sava River riparian zone. Data on total element concentrations and calculated background values for the SRB are listed in Table 1 with results representing the average of 5 independent analyses. Deviation from the average value for all elements did not exceed $\pm 5 \%$.

PTE concentrations varied among the sampling localities. In the upper and middle reaches, total concentrations were within the average values for European soils (Gawlik and Bidoglio 2006), while an increase in element concentrations was observed in the lower reaches. $\mathrm{As}, \mathrm{Cu}$, and $\mathrm{Zn}$ concentrations exceeded calculated background values at almost all the sampling sites, $\mathrm{Cr}$ and $\mathrm{Ni}$ in the lower stretch, while $\mathrm{Cd}$ and $\mathrm{Pb}$ concentrations fell mainly within the calculated background values (Table 1).

The level of potentially readily soluble element concentrations versus their total concentrations in soils is shown in Table 2 . The levels of the readily soluble fractions are generally low for $\mathrm{As}, \mathrm{Cr}, \mathrm{Cu}$, and $\mathrm{Pb}$ (below 1\%) and for $\mathrm{Ni}$ and $\mathrm{Zn}$ (below 4\%), while they are higher for $\mathrm{Cd}(3-40 \%)$.

\subsection{Source identification and ecological risk assessment of trace elements}

In our study, the Pearson correlation was applied to find the relationship between the studied elements. As Table S3 (Electronic Supplementary Material) shows, there was a significant positive correlation between the elements, apart from $\mathrm{Cu}$. PCA was applied to identify trace element sources in the riparian soil and showed three principal components (PC1, PC2, and PC3), which explained $95.03 \%$ of the total variability. PC1 included $67.75 \%$ of total variability; PC2, $14.22 \%$; and $\mathrm{PC} 3,13.06 \%$. PC1 corresponds to natural (lithogenic) factors, PC2 is based on the variability of elements controlled by natural factors such as the geological substrate and anthropogenic inputs, while PC3 relates to anthropogenic factors (Fig. 2 and Table S4, Electronic Supplementary Material). PC1 indicated the common, predominantly lithogenic origin of $\mathrm{Cr}, \mathrm{Mn}$, and $\mathrm{Ni}$, with their influence seen largely downstream (at SLB, SAB, ZUP, and SRM) (Fig. 2a, b). PC2 is mainly impacted by $\mathrm{Cd}, \mathrm{Pb}$, and $\mathrm{Zn}$, indicating both their geogenic and anthropogenic origin (Fig. 2a). Point-source pollution with the highest value in $\mathrm{PC} 2$ was observed for $\mathrm{Pb}$, which could be explained by anthropogenic factors at BEO, but also by the impact of chemical weathering and ore deposits, which is shown at MOJ (Fig. 2b). Arsenic was also shown to occur in both PC1 and PC2 with equally strong bonds, indicating both its anthropogenic and lithogenic origins, depending on the sampling site. The differentiation of $\mathrm{Cu}$ from the other components indicated an anthropogenic pollution source, which is highly marked at CAT, with the impact transferred downstream to ZAG and JAS (Fig. 2b). MLRA indicated the dominant influence of a factor that does not belong to the main components for all elements except $\mathrm{Cu}$, $\mathrm{Cr}$, and $\mathrm{Ni}$. In the Sava's case, this could refer to frequent water level fluctuations and sediment deposition on the soil's surface layers (Fig. 3).

The EF was calculated for all sites and generally, the order of average values was $\mathrm{Cu}>\mathrm{Zn}>\mathrm{Cr}>\mathrm{Ni}>\mathrm{As}>\mathrm{Pb}>\mathrm{Cd}$ (Table 3). Values ranged from minor to moderate enrichment, depending on the site, and were only in the significant range for $\mathrm{Cu}$ at $\mathrm{CAT}$. The mean $E_{i}$ calculated for all sites can be ranked in the following order: $\mathrm{Cd}>\mathrm{As}>\mathrm{Cu}>\mathrm{Ni}>\mathrm{Pb}>\mathrm{Cr}$ $>\mathrm{Zn}$, with $\mathrm{Cd}$ having the highest value (32.27) and $\mathrm{Zn}$ the lowest (1.80). Individual $E_{i}$ values were mostly in the low-risk category, apart from $\mathrm{Cd}$ in the river's lower reaches (at SRM, $\mathrm{SAB}$, and $\mathrm{BEO}$ ), where it ranged from moderate to considerable. The RI was calculated for all sites, with the highest value at BEO (215.2) and the lowest at LIT (28.17). Moderate RI was observed only at BEO (Table 4).

\section{Discussion}

Due to their unique semi-terrestrial position, riparian zones are remarkably sensitive to alterations in flow, temperature, landscape composition, and anthropogenic pressures. PTE enter these zones as a result of the weathering of parent rocks and anthropogenic activities, as well as floods, and are incorporated into sediments and soils as pollutants (Xie et al. 2014; Milačič et al. 2017). With PTE concentrations in rivers increasing markedly in Europe during the nineteenth and twentieth centuries (Schulz-Zunkel et al. 2013), determining their levels in natural waters and sediments is of great importance, so as to investigate the geochemical migration of chemical species and also substantiate environmental pollution in aquatic systems due to human activities (Vertačnik and Bišćan 1993). Multivariate statistics have proven to be a powerful tool for identifying geogenic and anthropogenic groups of chemical elements, which is vital as the latter are more mobile and bioavailable (Šajn and Gosar 2014).

According to Alloway (2013), average As concentrations in soils range from 5 to $7.5 \mathrm{mg} \mathrm{kg}^{-1}$, while there is no data on 
Table 1 Total content of potentially toxic elements in soils from the Sava River riparian zone. The values are mean (SD)

\begin{tabular}{|c|c|c|c|c|c|c|c|}
\hline \multirow{2}{*}{$\begin{array}{l}\text { Sampling } \\
\text { sites }\end{array}$} & \multicolumn{7}{|c|}{ Elements ( $\mathrm{mg} \mathrm{kg}^{-1}$ dry weight) } \\
\hline & As & $\mathrm{Cd}$ & $\mathrm{Cu}$ & $\mathrm{Cr}$ & $\mathrm{Ni}$ & $\mathrm{Pb}$ & $\mathrm{Zn}$ \\
\hline MOJ & $10.57(0.96)$ & $0.18(0.02)$ & $17.91(0.85)$ & $36.28(0.98)$ & $15.60(0.59)$ & $78.14(1.46)$ & $180.13(5.13)$ \\
\hline RAD & $7.59(0.64)$ & $0.23(0.02)$ & $32.73(1.23)$ & $60.65(1.96)$ & $27.36(1.61)$ & $45.74(1.37)$ & $182.01(3.91)$ \\
\hline LIT & $9.32(0.74)$ & $0.13(0.01)$ & $31.17(0.78)$ & $42.53(1.25)$ & $22.88(1.21)$ & $27.61(0.76)$ & $91.67(4.09)$ \\
\hline VRH & $11.25(0.55)$ & $0.27(0.03)$ & $26.69(0.76)$ & $62.14(1.81)$ & $28.93(1.59)$ & $31.64(0.83)$ & $109.26(2.55)$ \\
\hline CAT & $12.70(0.94)$ & $0.62(0.06)$ & $148.62(1.79)$ & $77.96(2.01)$ & $36.81(1.71)$ & $43.94(0.64)$ & $170.38(3.53)$ \\
\hline ZAG & $8.68(0.57)$ & $0.31(0.03)$ & $65.02(1.53)$ & $52.16(1.83)$ & $24.47(1.37)$ & $21.07(0.44)$ & $114.48(2.15)$ \\
\hline JAS & $8.26(0.66)$ & $0.18(0.02)$ & $67.71(1.84)$ & $38.07(1.25)$ & $22.40(1.14)$ & $22.50(0.45)$ & $104.44(3.00)$ \\
\hline SLB & $13.89(0.90)$ & $0.31(0.03)$ & $39.28(1.12)$ & $161.55(3.57)$ & $85.83(4.12)$ & $25.77(0.70)$ & $109.92(4.72)$ \\
\hline ZUP & $16.18(0.89)$ & $0.38(0.04)$ & $51.31(1.97)$ & $282.79(5.83)$ & $165.73(12.16)$ & $42.99(1.36)$ & $170.99(5.28)$ \\
\hline SRM & $16.30(0.63)$ & $1.44(0.14)$ & $42.7(0.87)$ & $265.11(12.36)$ & $122.68(5.93)$ & $50.91(0.95)$ & $192.86(6.06)$ \\
\hline SAB & $21.29(1.36)$ & $1.61(0.16)$ & $41.33(1.49)$ & $235.85(7.01)$ & $152.60(7.89)$ & $58.78(1.77)$ & $224.61(8.70)$ \\
\hline $\mathrm{BEO}$ & $29.33(1.87)$ & $3.11(0.31)$ & $63.74(1.28)$ & $221.67(5.16)$ & $168.04(6.89)$ & $83.60(2.12)$ & $328.29(6.86)$ \\
\hline $\begin{array}{l}\text { Calculated } \\
\text { background values }\end{array}$ & 11.53 & 0.68 & 24.12 & 72.52 & 41.33 & 44.03 & 91.64 \\
\hline $\begin{array}{l}\text { Background values } \\
\text { for European soils } \mathrm{s}^{\mathrm{a}}\end{array}$ & - & $1-3$ & $50-140$ & $50-100$ & $30-75$ & $50-300$ & $150-300$ \\
\hline
\end{tabular}

${ }^{\text {a }}$ Proposed threshold values for European soils according to Directive 86/278/EEC (Gawlik and Bidoglio 2006)

background As values for European soils. In this study, As concentrations ranged from 7.6 to $29.3 \mathrm{mg} \mathrm{kg}^{-1}$ (Table 1) and were generally lower than those found in the alluvial soils of the Drava (7-54 $\mathrm{mg} \mathrm{kg}^{-1}$, Šajn et al. 2011), but higher than those reported for the Sava in earlier studies $\left(5-18 \mathrm{mg} \mathrm{kg}^{-1}\right.$, Halamić et al. 2003). With As affecting both PC1 and PC2, its origin in the Sava's riparian soil could be both lithogenic and anthropogenic, which is supported by As correlating closely with $\mathrm{Mn}, \mathrm{Cr}$, and $\mathrm{Ni}$ and with $\mathrm{Pb}, \mathrm{Zn}$, and $\mathrm{Cd}$ (Table $\mathrm{S} 3$, Electronic Supplementary Material). In the river's upper reaches, EF values showed moderate enrichment, indicating mixed geogenic and anthropogenic influences, which most likely originate from ore deposits and the steel industry at Jesenice (Vidmar et al. 2017) (Fig. 2a). In the lower reaches, total As concentrations increase, while the potentially available portion of As decreases. Here, EF values pointed to the mainly lithogenic origin of As at SLB, ZUP, and SAB, but its anthropogenic origin at BEO (Fig. 2b).

In the present study, total $\mathrm{Cd}$ concentrations increased along the Sava, varying from $0.13 \mathrm{mg} \mathrm{kg}^{-1}$ at LIT to $3.11 \mathrm{mg} \mathrm{kg}^{-1}$ at BEO. Levels were mostly below background values for European soils (1-3 $\mathrm{mg} \mathrm{kg}^{-1}$ ) (Gawlik and Bidoglio 2006), except at BEO (Table 1), and were similar to those reported in a previous study on the Sava (Vertačnik et al. 1995), but lower than those at the Drava $\left(0.10-17 \mathrm{mg} \mathrm{kg}^{-1}\right.$, Šajn et al. 2011). The low total concentrations indicate that $\mathrm{Cd}$ does not pose an ecological risk, a fact supported by the minimal enrichment EF values (Tables 3 and 4). However, downstream, at $\mathrm{SAB}$ and $\mathrm{BEO}$, total concentrations were higher (> $1 \mathrm{mg} \mathrm{kg}^{-1}$, Table 1), most probably due to anthropogenic sources (Fig. 2a, b), such as untreated sewage water, and the chemical and metal industries (Milačič et al. 2017). Its mixed origin in soil was highlighted by PCA ( $\mathrm{Cd}$ extracted in PC2) and its close correlation with $\mathrm{As}, \mathrm{Cr}, \mathrm{Ni}, \mathrm{Pb}$, and $\mathrm{Zn}$ (Table $\mathrm{S} 3$, Electronic Supplementary Material; Figs. 2 and 3). These high $\mathrm{Cd}$ concentrations are also a result of the reduction of river flow, leading to $\mathrm{Cd}$ accumulation. Levels of bioavailable $\mathrm{Cd}$ decreased with distance downstream with $>20 \%$ in the upper reaches (Table 2) due to its high solubility (Mitchell et al. 2016) and $<10 \%$ in the lower stretch as it probably becomes

Table 2 Readily soluble concentrations of the investigated elements in soils in the Sava River riparian zone

\begin{tabular}{llllllll}
\hline Sampling sites & \multicolumn{7}{l}{ Readily soluble concentrations $(\%)$} \\
\cline { 2 - 8 } & As & $\mathrm{Cd}$ & $\mathrm{Cu}$ & $\mathrm{Cr}$ & $\mathrm{Ni}$ & $\mathrm{Pb}$ & $\mathrm{Zn}$ \\
\hline MOJ & 1.05 & 38.19 & 0.21 & 0.04 & 0.09 & 0.05 & 3.34 \\
RAD & 0.13 & 25.36 & 0.21 & 0.06 & 2.75 & 0.09 & 3.40 \\
LIT & 0.12 & 19.49 & 0.23 & 0.01 & 1.47 & 0.02 & 1.88 \\
VRH & 0.09 & 17.13 & 0.23 & $<$ LoQ & 1.11 & 0.01 & 1.98 \\
CAT & 0.12 & 10.06 & 0.31 & 0.02 & 0.90 & $<$ LoQ & 2.14 \\
ZAG & 0.21 & 6.96 & 0.05 & 0.01 & 0.58 & $<$ LoQ & 0.62 \\
JAS & 0.14 & 24.96 & 0.05 & 0.01 & 1.04 & $<$ LoQ & 1.99 \\
SLB & 0.11 & 7.09 & 0.07 & 0.00 & 0.33 & $<$ LoQ & 0.25 \\
ZUP & 0.18 & 9.21 & 0.06 & 0.00 & 0.44 & $<$ LoQ & 0.46 \\
SRM & 0.18 & 4.23 & 0.09 & 0.00 & 0.56 & $<$ LoQ & 0.57 \\
SAB & 0.17 & 3.09 & 0.07 & 0.01 & 0.37 & $<$ LoQ & 0.55 \\
BEO & 0.15 & 5.76 & 0.10 & 0.00 & 0.45 & $<$ LoQ & 0.73 \\
\hline
\end{tabular}


$\mathbf{a}$

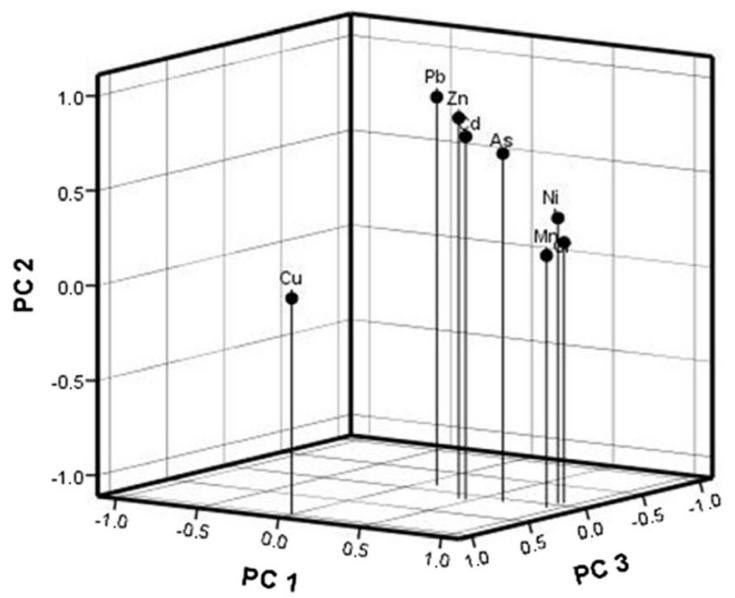

b

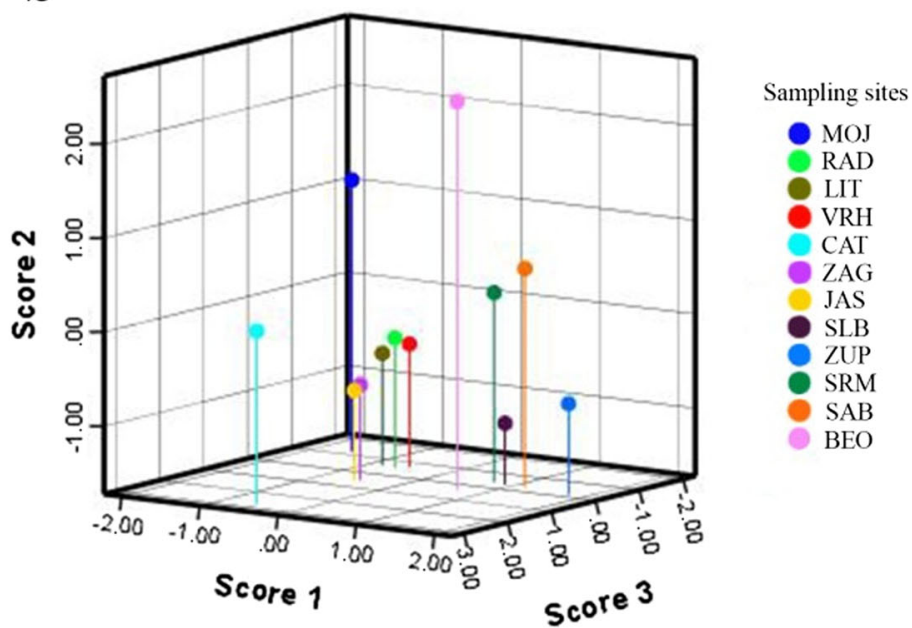

Fig. 2 a PCA loading plot for soil samples in the riparian zone of the Sava River. b Graphic score for soil samples in the riparian zone of the Sava River for 12 sampling sites (MOJ, RAD, LIT, VRH, CAT, ZAG, JAS, SLB, ZUP, SRM, SAB, and BEO)

bound due to various more sparingly soluble chemical phases (Ashraf et al. 2012; Mitchell et al. 2016). Higher than the proposed threshold values, the total $\mathrm{Cd}$ content impacted on a particularly high $E_{i}$ (considerable potential ecological risk) and, as such, on the overall RI (Table 4). Hence, due to its pronounced toxicity and since $\mathrm{Cd}$ comprises at least $50 \%$ of the overall RI, it can potentially represent an ecological risk in the Sava's lower reaches (Table S5, Electronic Supplementary Material).

Copper showed considerable concentration variations, from 18 to $149 \mathrm{mg} \mathrm{kg}^{-1}$ (Table 1). At all sampling sites, concentrations are lower in relation to background values for European soils (50-140 mg kg ${ }^{-1}$, Gawlik and Bidoglio 2006), except at CAT. Generally, our study revealed higher concentrations than those from earlier studies on the riparian soils of the Sava (12-35 $\mathrm{mg} \mathrm{kg}^{-1}$, Halamić et al. 2003) and the Odra (0.44-75.29 $\mathrm{mg} \mathrm{kg}^{-1}$, Ciesielczuk et al. 2014). Individual and localized pollution resulted in the differentiation of $\mathrm{Cu}$ from other components in the PCA, indicating a specific anthropogenic source of pollution (Fig. 2a, b), a fact supported by MLRA (Fig. 3). EF levels revealed minor enrichment, apart from at RAD, LIT, ZAG, and JAS (moderate enrichment), (Table 3). At CAT, significant enrichment was found, probably due to industrial activities (the paper and
Fig. 3 Apportionment percentage of possible source types (lithogenic, mixed lithogenic and anthropogenic, anthropogenic, other) based on observed PTE concentrations (MLR analysis)

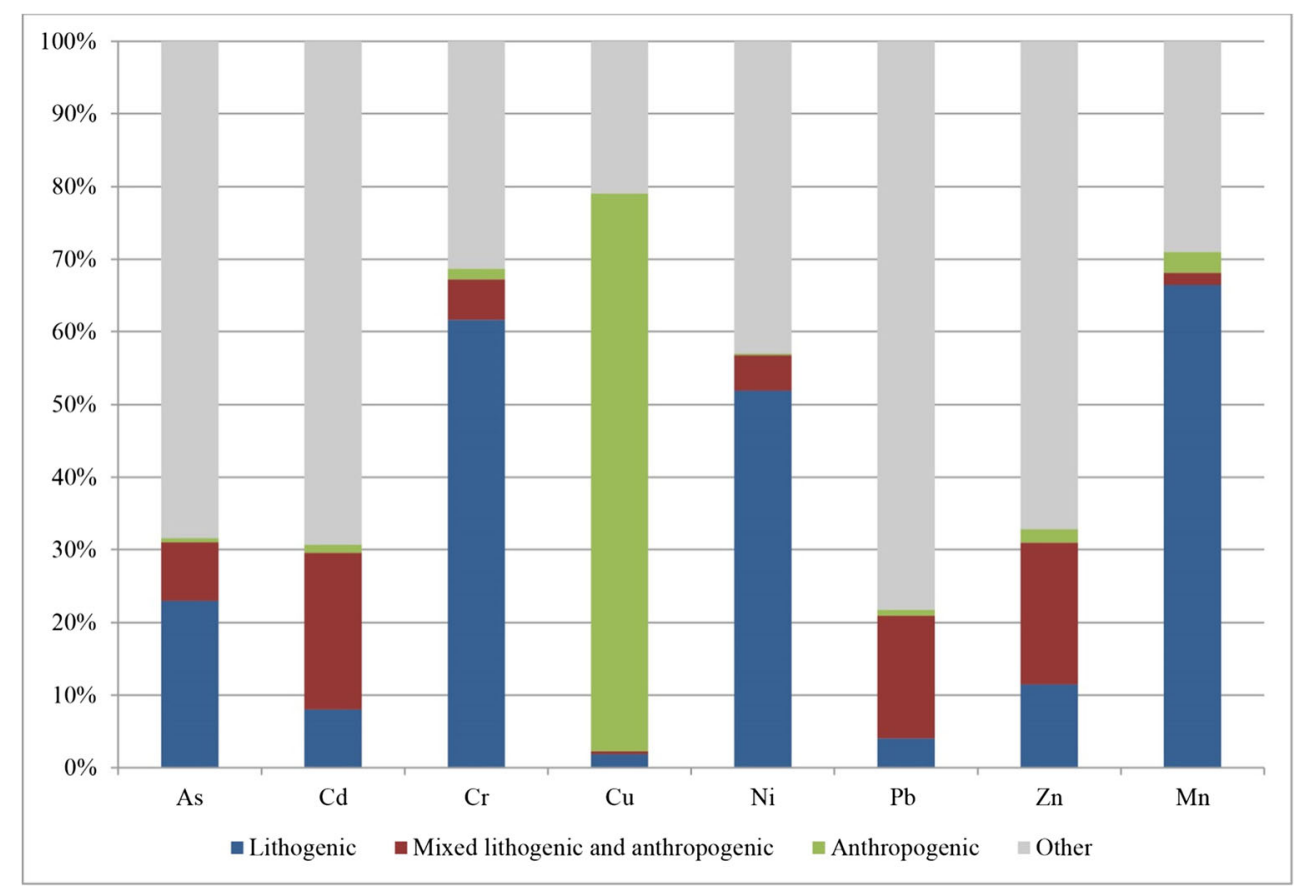


Table 3 Enrichment factors (EF) for soils in the Sava River riparian zone

\begin{tabular}{llllllll}
\hline Sampling sites & \multicolumn{7}{l}{ Enrichment factor (EF) } \\
\cline { 2 - 8 } & As & $\mathrm{Cd}$ & $\mathrm{Cu}$ & $\mathrm{Cr}$ & $\mathrm{Ni}$ & $\mathrm{Pb}$ & $\mathrm{Zn}$ \\
\hline MOJ & 2.31 & 0.67 & 1.87 & 1.26 & 0.95 & 4.48 & 4.96 \\
RAD & 1.10 & 0.55 & 2.26 & 1.39 & 1.10 & 1.73 & 3.31 \\
LIT & 2.69 & 0.62 & 4.30 & 1.95 & 1.84 & 2.09 & 3.33 \\
VRH & 1.70 & 0.70 & 1.93 & 1.50 & 1.22 & 1.26 & 2.08 \\
CAT & 1.40 & 1.17 & 7.86 & 1.37 & 1.14 & 1.27 & 2.37 \\
ZAG & 1.27 & 0.78 & 4.56 & 1.22 & 1.00 & 0.81 & 2.11 \\
JAS & 1.15 & 0.43 & 4.51 & 0.84 & 0.87 & 0.82 & 1.83 \\
SLB & 0.93 & 0.35 & 1.26 & 1.72 & 1.61 & 0.45 & 0.93 \\
ZUP & 0.87 & 0.35 & 1.32 & 2.42 & 2.49 & 0.61 & 1.16 \\
SRM & 1.50 & 2.26 & 1.89 & 3.89 & 3.16 & 1.23 & 2.24 \\
SAB & 1.25 & 1.61 & 1.16 & 2.21 & 2.51 & 0.91 & 1.66 \\
BEO & 1.76 & 3.17 & 1.83 & 2.12 & 2.82 & 1.32 & 2.49 \\
Min & 0.87 & 0.35 & 1.16 & 0.84 & 0.87 & 0.45 & 0.93 \\
Max & 2.69 & 3.17 & 7.86 & 3.89 & 3.16 & 4.48 & 4.96 \\
Mean & 1.50 & 1.05 & 2.90 & 1.83 & 1.73 & 1.41 & 2.37 \\
\hline
\end{tabular}

wood processing industry, ISRBC 2016). In addition, frequent $\mathrm{Cu}$ use in agriculture and different metallurgical processes, such as the production of steel and steel products, can also be a source of soil contamination (Alloway 2013). Although EF indicated significant enrichment, potential ecological risk (RI) was low, indicating that $\mathrm{Cu}$ does not pose an ecological risk in that area (Table 4 and Table S5, Electronic Supplementary Material).

Total $\mathrm{Cr}$ soil concentrations, ranging from $36.3 \mathrm{mg} \mathrm{kg}^{-1}$ (at MOJ) to $282.8 \mathrm{mg} \mathrm{kg}^{-1}$ (at ZUP), were similar to those determined in alluvial soil at the Drava (40-250 $\mathrm{mg} \mathrm{kg}^{-1}$, Šajn et al.
2011), but higher than those found in earlier studies on the Sava (Vertačnik et al. 1995). Ni soil concentrations, ranging from 15.6 to $168 \mathrm{mg} \mathrm{kg}^{-1}$, were similar to those reported for the Kolubara (17.9-178.4 mg kg ${ }^{-1}$, Čakmak et al. 2018), but were higher than those at the Drava $\left(18-61 \mathrm{mg} \mathrm{kg}^{-1}\right.$, Šajn et al. 2011) and the Odra River $\left(0.90-16.13 \mathrm{mg} \mathrm{kg}^{-1}\right.$; Ciesielczuk et al. 2014). From MOJ down to JAS, total $\mathrm{Cr}$ and $\mathrm{Ni}$ content was in line with average concentrations for European soils (50-100 mg kg${ }^{-1}$ for $\mathrm{Cr} ; 30-75 \mathrm{mg} \mathrm{kg}^{-1}$ for $\mathrm{Ni}$, Gawlik and Bidoglio 2006). However, from JAS to BEO, levels increased and exceeded threshold values (Table 1). PCA and MLRA showed that $\mathrm{Cr}$ and $\mathrm{Ni}$ are both lithogenic in origin (Figs. 2 and 3), mainly from the weathering of parent materials, particularly mafic and ultramafic rocks (Alloway 2013), with the Dinaric Ophiolite Belt contributing to elevated $\mathrm{Cr}$ and Ni concentrations in the SRB (Mrvić et al. 2011; Grba et al. 2015). In the lower reaches, from ZUP to BEO, the geological substrate has the greatest impact on $\mathrm{Cr}$ and $\mathrm{Ni}$ soil content, which is also affected by erosion and fluvial processes from the Drina and Kolubara (Belanović-Simić et al. 2013; Čakmak et al. 2018) (Fig. 2a, b). However, elevated concentrations also arise from local anthropogenic pollution sources (Milačič et al. 2017), as shown by the slightly elevated, moderate enrichment levels in all but the upper reaches (minor enrichment) (Table 3). However, despite the high $\mathrm{Cr}$ and $\mathrm{Ni}$ concentrations in the Sava's lower stretch, their impact on RI is insignificant (Table 4).

Total $\mathrm{Pb}$ soil concentrations, ranging from 21 to $83.6 \mathrm{mg} \mathrm{kg}^{-1}$, were similar to those reported in a previous Sava study (18-58 $\mathrm{mg} \mathrm{kg}^{-1}$, Halamić et al. 2003), but higher than at the Kolubara (8.8-24.5 mg kg ${ }^{-1}$, Čakmak et al. 2018) and Odra (0.96-22.01 $\mathrm{mg} \mathrm{kg}^{-1}$, Ciesielczuk et al. 2014), yet still within the proposed background values for European soils (50-300 mg kg${ }^{-1}$ ) at all localities (Table 1). In general, $\mathrm{Pb}$
Table 4 Ecological risk index for individual elements $\left(E_{i}\right)$ and the potential ecological risk index (RI) for the environment for soils in the Sava River riparian zone

\begin{tabular}{lrrrrrrrr}
\hline \multirow{2}{*}{ Sampling sites } & \multicolumn{9}{l}{ Individual ecological risk index $\left(E_{i}\right)$} & & & \multirow{2}{*}{ RI } \\
\cline { 2 - 7 } & \multicolumn{1}{c}{ As } & \multicolumn{1}{c}{$\mathrm{Cd}$} & \multicolumn{1}{c}{$\mathrm{Cu}$} & $\mathrm{Cr}$ & $\mathrm{Ni}$ & $\mathrm{Pb}$ & $\mathrm{Zn}$ & \\
\hline MOJ & 9.17 & 7.94 & 3.71 & 1.00 & 1.89 & 8.87 & 1.97 & 34.55 \\
RAD & 6.58 & 9.93 & 6.79 & 1.67 & 3.31 & 5.19 & 1.99 & 35.46 \\
LIT & 8.09 & 5.55 & 6.46 & 1.17 & 2.77 & 3.14 & 1.00 & 28.17 \\
VRH & 9.75 & 12.08 & 5.53 & 1.71 & 3.50 & 3.59 & 1.19 & 37.37 \\
CAT & 11.01 & 27.45 & 30.81 & 2.15 & 4.45 & 4.99 & 1.86 & 82.72 \\
ZAG & 7.53 & 13.90 & 13.48 & 1.44 & 2.96 & 2.39 & 1.25 & 42.94 \\
JAS & 7.16 & 8.07 & 14.04 & 1.05 & 2.71 & 2.56 & 1.14 & 36.72 \\
SLB & 12.05 & 13.60 & 8.14 & 4.46 & 10.38 & 2.93 & 1.20 & 52.76 \\
ZUP & 14.03 & 16.85 & 10.64 & 7.80 & 20.05 & 4.88 & 1.87 & 76.11 \\
SRM & 14.14 & 63.66 & 8.86 & 7.31 & 14.84 & 5.78 & 2.10 & 116.69 \\
SAB & 18.46 & 70.99 & 8.57 & 6.50 & 18.46 & 6.68 & 2.45 & 132.11 \\
BEO & 25.44 & 137.25 & 13.21 & 6.11 & 20.33 & 9.49 & 3.58 & 215.42 \\
Mean & 11.95 & 32.27 & 10.85 & 3.53 & 8.80 & 5.04 & 1.80 & \\
\hline
\end{tabular}


concentrations were consistent along the Sava, apart from at MOJ, where higher concentrations could be due to the chemical weathering of parent material and ore deposits, and at $\mathrm{BEO}$, due to upstream industrial activities. Lead correlates closely with $\mathrm{As}, \mathrm{Cd}$, and $\mathrm{Zn}$, which are extracted in a separate group in PC2 (Fig. 2a, b). Indeed, $\mathrm{Pb}$ accumulates in soil in the surface horizons, mostly from anthropogenic sources (Alloway 2013). However, the $\mathrm{EF}$ for $\mathrm{Pb}$ was generally low, again with the exception of MOJ (moderate EF), and while point and diffuse sources of $\mathrm{Pb}$ pollution, such as industrial activities, mining and smelting, and leaded gasoline emissions, pose a high environmental risk, in this study, potentially bioavailable concentrations were mostly below the limit of quantification $(<\mathrm{LoQ})$ and $E_{i}$ was low, indicating that $\mathrm{Pb}$ does not present an environmental risk (Tables 2 and 4 ).

Total $\mathrm{Zn}$ concentrations, ranging from $91.7 \mathrm{mg} \mathrm{kg}^{-1}$ (LIT) to $328.3 \mathrm{mg} \mathrm{kg}^{-1}$ (BEO), were within the values for European soils (150-300 mg kg-1; Gawlik and Bidoglio 2006) at all localities except BEO (Table 1). While levels were similar to an earlier Sava study by Vertačnik et al. (1995), they were higher than those in a second study (53-135 mg kg-1, Halamić et al. 2003) and another on the Kolubara (36$126 \mathrm{mg} \mathrm{kg}^{-1}$, Čakmak et al. 2018). Zinc in soils mainly depends on the type of parent material; however, apart from geological processes, $\mathrm{Zn}$ sources are generally related to anthropogenic activities, such as mining, smelting, and the application of different fertilizers (Adriano 2001; Alloway 2013). In this study, PCA showed that $\mathrm{Zn}$ concentrations are mostly associated with PC2 (Fig. 2a, b), with it correlating closely with $\mathrm{As}, \mathrm{Cd}$, and $\mathrm{Pb}$ (Table $\mathrm{S} 3$, Electronic Supplementary Material). Downstream, from ZUP to BEO, Zn levels increased noticeably, particularly at BEO, with the source potentially being untreated sewage waters (Milačič et al. 2017; Adamiec et al. 2016). The EF for Zn was 2-5, reflecting moderate enrichment for MOJ, RAD, LIT, VRH, CAT, ZAG, SRM, and BEO (Table 3). However, the percentage of bioavailable $\mathrm{Zn}$ was below $4 \%$ and $E_{i}<40$, indicating an insignificant ecological risk (Tables 2 and 4).

This study revealed that PTE levels in riparian soil increased with distance from the Sava's source; however, for the most part, their levels in low-water conditions do not pose a potential risk to the riverine environment, the only exception being the high total Cd concentrations in soil in the lower reaches of the Sava. The remobilization of this element under extreme flow events from riparian soil into the water column could pose a considerable ecological risk to the riverine ecosystem.

\section{Conclusions}

In this study, results obtained from 12 sampling sites revealed that PTE in the upper part of the Sava River was mostly in the range of the threshold values proposed for European soils, with the exception of $\mathrm{Cu}$, which exceeded the proposed values at CAT, with the impact transferred downstream to ZAG and JAS. Despite the high EF at CAT, though, this element, which is of predominantly anthropogenic origin, is characterized by low individual and overall ecological indices, meaning it does not represent a potential ecological risk in this area. At the downstream sites, there was a noticeable increase in PTE content in the examined soils, with $\mathrm{Cd}, \mathrm{Cr}, \mathrm{Ni}$, and $\mathrm{Zn}$ exceeding the proposed values. This indicates that contamination in the riparian zone in comparison to that in previous studies conducted in alluvial soils along the Sava River is rising. It was established that the origin of $\mathrm{Cr}$ and $\mathrm{Ni}$ in soil is lithological. Due to their low enrichment and bioavailability, $\mathrm{Cr}$ and $\mathrm{Ni}$ do not present an ecological risk. The other elements were shown to be of both lithological and anthropogenic in origin, depending on the sampling site. The ecological risk indicators for $\mathrm{As}, \mathrm{Pb}$, and $\mathrm{Zn}$ showed that these elements have a minor to moderate impact. However, the high total $\mathrm{Cd}$ content in the lower stretch affected individual and overall ecological risk indicators, demonstrating that $\mathrm{Cd}$ could represent a considerable ecological risk for the downstream riparian zone, especially at BEO.

Since there is an increased accumulation of PTE in the lower part of the river, any future flood or high-water events could lead to their remobilization due to a change in physical and chemical soil conditions, posing a considerable ecological risk to the riparian zone.

Funding information This work has been supported by the European Communities 7th Framework Programme Funding under grant agreement no. 603629-ENV-2013-6.2.1-Globaqua. The preparation of this manuscript was supported by the Ministry of Education, Science and Technological Development of the Republic of Serbia, grant no. 173018.

Open Access This article is distributed under the terms of the Creative Commons Attribution 4.0 International License (http://creativecommons. org/licenses/by/4.0/), which permits unrestricted use, distribution, and reproduction in any medium, provided you give appropriate credit to the original author(s) and the source, provide a link to the Creative Commons license, and indicate if changes were made.

\section{References}

Adamiec E, Jarosz-Krzemińska E, Wieszała R (2016) Heavy metals from non-exhaust vehicle emissions in urban and motorway road dusts. Environ Monit Assess 188:369

Adriano DC (2001) Trace elements in terrestrial environments. Biogeochemistry, bioavailability, and risk of metals. SpringerVerlag, Berlin ISBN 978-0-387-21510-5

Alloway JB (2013) Heavy metals in soil. Trace metals and metalloids in soil and their bioavailability. Springer, Dordrecht ISBN 978-94-0074470-7

Ashraf MA, Maah MJ, Yusoff I (2012) Chemical speciation and potential mobility of heavy metals in the soil of former tin mining catchment. Sci World J 2012:125608

Bain DJ, Yesilonis ID, Pouyat RV (2012) Metal concentrations in urban riparian sediments along an urbanization gradient. Biogeochemistry $107: 67-79$ 
Belanović-Simić S, Perović V, Vidojević D, Kostadinov S, Knežević M, Kadović R, Kođanin O (2013) Assessment of soil erosion intensity in Kolubara District, Serbia. Fresenius Environ Bull 22(5a):15561563

Birch GF (2017) Determination of sediment metal background concentrations and enrichment in marine environments - a critical review. Sci Total Environ 580:813-831

Borůvka L, Vacek O, Jehlička J (2005) Principal component analysis as a tool to indicate the origin of potentially toxic elements in soils. Geoderma 128:289-300

Cakmak D, Saljnikov E, Skrivanj S, Roglic G, Bakrac S, Sikiric B, Manojlović D (2015) Identification of different sources and forms of arsenic in the vicinity of ore mining in Serbia. Fresenius Environ Bull 12b:4635-4643

Čakmak D, Perović V, Antić-Mladenović S, Kresović M, Saljnikov E, Mitrović M, Pavlović P (2018) Contamination, risk, and source apportionment of potentially toxic microelements in river sediments and soil after extreme flooding in the Kolubara River catchment in Western Serbia. J Soils Sediments 18:1981-1993

Ciesielczuk T, Kusza G, Poluszyńska J, Kochanowska K (2014) Pollution of flooded arable soils with heavy metals and polycyclic aromatic hydrocarbons (PAHs). Water Air Soil Pollut 225:2145

Crnković DM, Crnković NS, Filipović AJ, Rajaković LV, Perić-Grujić AA, Ristić MD (2008) Danube and Sava river sediment monitoring in Belgrade and its surroundings. J Environ Sci Health A Tox Hazard Subst Environ Eng 43(12): 1353-1360

EC (2000) Directive 2000/60/EC of the European Parliament and of the Council Establishing a framework for Community action in the field of water policy L 327/1. Official Journal of the European Communities, Luxembourg

EU (2013) Directive 2013/39/EU of the European Parliament and of the Council of 12 August 2013 amending Directives 2000/60/EC and 2008/105/EC as regards priority substances in the field of water policy. Official Journal of the European Communities, Luxembourg

Gawlik BW, Bidoglio G (2006) Background values in European soils and sewage sludges PART III, Conclusions, comments and recommendations. European Commission, Directorate-General Joint Research Centre, Institute for Environment and Sustainability

Grba N, Neubauer F, Sajnovic A, Stojanovic K, Jovancicevic B (2015) Heavy metals in neogene sedimentary rocks as a potential lithogenic hazard for sediment, soil, surface and groundwater contamination (Eastern Posavina and Lopare Basin, Bosnia and Herzegovina). J Serb Chem Soc 80:827-838

Hakanson L (1980) An ecological risk index for aquatic pollution control. A sedimentological approach. Water Res 14:975-1001

Halamić J, Galović L, Šparica M (2003) Heavy metal (As, Cd, Cu, Hg, Pb and $\mathrm{Zn}$ ) distribution in topsoil developed on alluvial sediments of the Drava and Sava Rivers in NW Croatia. Geol Croat 56:215-232

Halamić J, Peh Z, Miko S, Galović L, Šorša A (2012) Geochemical atlas of Croatia: environmental implications and geodynamical thread. J Geochem Explor 115:36-46

Hu Y, Liu X, Bai J, Shih K, Zeng EY, Cheng H (2013) Assessing heavy metal pollution in the surface soils of a region that had undergone three decades of intense industrialization and urbanization. Environ Sci Pollut Res 20:6150-6159

ISRBC (2013) Towards practical guidance for sustainable sediment management using the Sava River Basin as a showcase estimation of sediment balance for the Sava River

ISRBC (2016) Towards practical guidance for sustainable sediment management using the Sava River basin as a showcase. Estimation of sediment balance for the Sava River. International Sava River basin commission (ISRBC) https://en.unesco.org/news/towards-practicalguidance-sustainable-sediment-management-using-sava-riverbasin-showcase
Izquierdo M, Tye AM, Chenery SR (2013) Lability, solubility and speciation of $\mathrm{Cd}, \mathrm{Pb}$ and $\mathrm{Zn}$ in alluvial soils of the River Trent catchment UK. Environ Sci Process Impacts 15:1844-1858

Jiang X, Xiong Z, Liu H, Liu G, Liu W (2017) Distribution, source identification, and ecological risk assessment of heavy metals in wetland soils of a river-reservoir system. Environ Sci Pollut Res $24: 436-444$

Karadžić B, Jarić S, Pavlović P, Mitrović M (2015) Aquatic and wetland vegetation along the Sava River. In: Milačič R, Ščančar J, Paunović M (eds) The Sava River, the handbook of environmental chemistry, vol 31. Springer, Heidelberg, pp 249-316

Karr JR, Gorman OT (1975) Effects of land treatment on the aquatic environment In: Nonpoint source pollution Seminar USA. United States Environmental Protection Agency, Chicago, Illinois, USA. Technical Report EPA-906/9-75-007, pp 120-150

Komatina D, Grošelj S (2015) Transboundary water cooperation for sustainable development of the Sava River Basin. In: Milačič R, Ščančar J, Paunović M (eds) The Sava River, the handbook of environmental chemistry, vol 31. Springer, Heidelberg, pp 1-25

Loska K, Cebula J, Pelczar J, Wiechuła D, Kwapuliński J (1997) Use of enrichment, and contamination factors together with geoaccumulation indexes to evaluate the content of $\mathrm{Cd}, \mathrm{Cu}$, and $\mathrm{Ni}$ in the Rybnik water reservoir in Poland. Water Air Soil Pollut 93:347-365

Markovics R, Kanduč T, Szramek K, Golobočanin D, Milačič R, Ogrinc N (2010) Chemical dynamics of the Sava riverine system. J Environ Monit 12:2165-2176

Milačič R, Ščančar J, Murko S, Kocman D, Horvat M (2010) A complex investigation of the extent of pollution in sediments of the Sava River. Part 1: selected elements. Environ Monit Assess 163:263275

Milačič R, Zuliani T, Vidmar J, Oprčkal P, Ščančar J (2017) Potentially toxic elements in water and sediments of the Sava River under extreme flow events. Sci Total Environ 605/606:894-905

Mitchell N, Ramos Gomez MS, Guerrero Barrera AL, Yamamoto Flores L, Flores de la Torre JA, Avelar Gonzalez FJ (2016) Contaminated soils and sediments near mining sites in Aguascalientes, Mexico. Bull Environ Contam Toxicol 97:216-224

Mrvić V, Lj K-K, Čakmak D, Sikirić B, Brebanović B, Perović V, Nikoloski M (2011) Pedogeochemical mapping and background limit of trace elements in soils of Branicevo Province (Serbia). J Geochem Explor 109:18-25

N'guessan YM, Probst JL, Bur T, Probst A (2009) Trace elements in stream bed sediments from agricultural catchments (Gascogne region, S-W France): where do they come from? Sci Total Environ 407:2939-2952

Naiman RJ, Décamps H (1997) The ecology of interfaces: riparian zones. Annu Rev Ecol Syst 28:621-658

Navarro-Ortega A, Acuña V, Bellin A, Burek P, Cassiani G, ChoukrAllah R, Dolédec S, Elosegi A, Ferrari F, Ginebreda A, Grathwohl P, Jones C, Rault PK, Kok K, Koundouri P, Ludwig RP, Milacic R, Muñoz I, Paniconi C, Paunović M, Petrovic M, Sabater S, Skoulikidis NT, Slob A, Teutsch G, Voulvoulis N, Barceló D (2015) Managing the effects of multiple stressors on aquatic ecosystems under water scarcity. The GLOBAQUA project. Sci Total Environ 503-504:3-9

Orescanin V, Lulić S, Pavlović G, Mikelić L (2004) Granulometric and chemical composition of the Sava River sediments upstream and downstream of the Krsko nuclear power plant. Environ Geol 46: 605-613

Pavlović P, Mitrović M, Đorđević D, Sakan S, Slobodnik J, Liška I, Csanyi B, Jarić S, Kostić O, Pavlović D, Marinković N, Tubić B, Paunović M (2016) Assessment of the contamination of riparian soil and vegetation by trace metals - a Danube River case study. Sci Total Environ 540:396-409 
Pusey BJ, Arthington AH (2003) Importance of the riparian zone to the conservation and management of freshwater fish: a review. Mar Freshw Res 54:1-16

Quevauviller P, Rauret G, López-Sánchez JF, Rubio R, Ure A, Muntau H (1997) Certification of trace metal extractable contents in a sediment reference material (CRM 601) following a three-step sequential extraction procedure. Sci Total Environ 205:223-234

Rinklebe J, Franke C, Neue HU (2007) Aggregation of floodplain soils as an instrument for predicting concentrations of nutrients and pollutants. Geoderma 141:210-223

Saint-Laurent D, Gervais-Beaulac V, Baril F, Matteau C, Sébastien Berthelot J (2013) Spatial variability of heavy metal contamination in alluvial soils in relation to flood risk zones in southern Québec, Canada. Air Soil Water Res 6:1-13

Šajn R, Gosar M (2014) Multivariate statistical approach to identify metal sources in Litija area (Slovenia). J Geochem Explor 138:8-21. https://doi.org/10.1016/j.gexplo.2013.12.007

Šajn R, Halamić J, Peh Z, Galović L, Alijagić L (2011) Assessment of the natural and anthropogenic sources of chemical elements in alluvial soils from the Drava River using multivariate statistical methods. J Geochem Explor 110:278-289. https://doi.org/10.1016/j.gexplo. 2011.06.009

Sakan S, Đorđević D (2010) Evaluation of heavy metal contamination in sediments using the method of total digestion and determination of the binding forms - Tisza River Basin, Serbia. J Environ Sci Health A 45:783-794

Sakan S, Dević G, Relić D, Anđelković I, Sakan N, Đorđević D (2015) Risk assessment of trace element contamination in river sediments in Serbia using pollution indices and statistical methods: a pilot study. Environ Earth Sci 73:6625-6638

Ščančar J, Zuliani T, Turk T, Milačič R (2007) Organotin compounds and selected metals in the marine environment of Northern Adriatic Sea. Environ Monit Assess 127:271-282

Ščančar J, Heath E, Zuliani T, Horvat M, Kotnik J, Perko S, Milačič R (2015) Elements and persistent organic pollutants in the sediments of the Sava River. In: Milačič R, Ščančar J, Paunović M (eds) The Sava River, the handbook of environmental chemistry, vol 31. Springer, Heidelberg. ISBN 978-3-662-44033-9, pp 27-52

Schulz-Zunkel C, Krueger F, Rupp H, Meissner R, Gruber B, Gerisch M, Bork H-R (2013) Spatial and seasonal distribution of trace metals in floodplain soils. A case study with the Middle Elbe River, Germany. Geoderma 211-212:128-137

Sedell JR, Leone FN, Duval WS (1991) Water transportation and storage of logs. In: Meehan WR (ed) Influences of forest and rangeland management on salmonid fishes and their habitats. American Fisheries Society, Special Publication 19, Bethesda, Maryland, pp 325-368

Slovenian Environment Agency (2017) Environmental atlas of Slovenia. http://gis.arso.gov.si/atlasokolja/profile.aspx?id=Atlas_Okolja AXL@ARSO\&culture=en-US

SPSS Statistics for Windows, version 21 (2009) SPSS Inc., Chicago, Ill., USA, about SPSS Inc. http://www.spss.com.hk/corpinfo/history. htm. Accessed 15 Nov 2017

Sutherland RA (2000) Bed sediment-associated trace metals in an urban stream, Oahu, Hawaii. Environ Geol 39:611-627

Tessier A, Campbell PGC (1987) Partitioning of trace metals in sediments: relationship with bioavailability. Hydrobiologia 149:43-52

Vertačnik A, Bišćan J (1993) Behaviour of some microelements, trace elements and REE in the water-sediment system. J Radioanal Nucl Chem 175(5):401-403

Vertačnik A, Prohić E, Kozar S, Juračič M (1995) Behaviour of some trace elements in alluvial sediments, Zagreb water-well field area, Croatia. Water Res 29(1):237-246

Vidmar J, Zuliani T, Novak P, Drinčić A, Ščančar J, Milačič R (2017) Elements in water, suspended particulate matter and sediments of the Sava River. J Soils Sediments 17:1917-1927

Vignati D, Pardos M, Diserens J, Ugazio G, Thomas R, Dominik J (2003) Characterisation of bed sediments and suspension of the river Po (Italy) during normal and high flow conditions. Water Res 37:28472864

Vuković Z, Radenković M, Stanković S, Vuković D (2011) Distribution and accumulation of heavy metals in the water and sediments of the River Sava. J Serb Chem Soc 76:795-803

Wang Y, Yang L, Kong L, Liu E, Wang L, Zhu J (2015) Spatial distribution, ecological risk assessment and source identification for heavy metals in surface sediments from Dongping Lake, Shandong, East China. Catena 125:200-205

Woitke PJ, Wellmitz D, Helm M, Kube P, Lepom P, Litheraty P (2003) Analysis and assessment of heavy metal pollution in suspended solids and sediments of the river Danube. Chemosphere 51(8): 633-642

Xie Z, Sun Z, Zhang H, Zhai J (2014) Contamination assessment of arsenic and heavy metals in a typical abandoned estuary wetland - a case study of the Yellow River Delta Natural Reserve. Environ Monit Assess 186:7211-7232

Zhang H, Cui B, Xiao R, Zhao H (2010) Heavy metals in water, soils and plants in riparian wetlands in the Pearl River Estuary, South China. Procedia Environ Sci 2:1344-1354 